\title{
Phytoprotection
}

\section{Integrated weed management and weed species diversity}

\section{D.R. Clements, S.F. Weise et C.J. Swanton}

Volume 75, numéro 1, 1994

URI : https://id.erudit.org/iderudit/706048ar

DOI : https://doi.org/10.7202/706048ar

Aller au sommaire du numéro

\section{Éditeur(s)}

Société de protection des plantes du Québec (SPPQ)l

ISSN

0031-9511 (imprimé)

1710-1603 (numérique)

Découvrir la revue

\section{Citer cet article}

Clements, D., Weise, S. \& Swanton, C. (1994). Integrated weed management and weed species diversity. Phytoprotection, 75(1), 1-18.

https://doi.org/10.7202/706048ar

\section{Résumé de l'article}

Les méthodes alternatives de gestion des mauvaises herbes, telles que la gestion intégrée, peuvent permettre la persistance de populations de mauvaises herbes sous un seuil économique déterminé. Une diversité accrue des espèces de mauvaises herbes peut aussi en résulter. Si la diversité ainsi que le nombre d'interactions écologiques augmentent, les espèces de mauvaises herbes devraient être considérées comme une communauté interactive plutôt que comme un ensemble disparate de cibles contre lesquelles lutter. Cet article de synthèse résume les méthodes d'évaluation de la diversité dans des systèmes non gérés, examine comment les techniques de gestion intégrée peuvent modifier la diversité des espèces de mauvaises herbes, et finalement, suggère des façons de développer des stratégies pour gérer la diversité des mauvaises herbes par la gestion intégrée de celles-ci. Les méthodes utilisées pour évaluer la diversité dans les systèmes naturels peuvent servir à évaluer la diversité des mauvaises herbes dans des systèmes alternatifs de gestion intégrée. Nous avons effectué des calculs préliminaires de diversité pour le labour réduit, l'utilisation modifiée des herbicides, les rotations culturales, la période critique d'intervention contre les mauvaises herbes, les techniques d'amélioration de la compétitivité des cultures et les méthodes de lutte alternatives. Plusieurs de ces techniques de gestion intégrée peuvent éventuellement résulter en des modifications de la diversité des espèces de mauvaises herbes. Nous avons examiné les effets potentiels de ces changements sur la diversité des mauvaises herbes à l'intérieur de six principaux éléments de l'écologie des communautés: la colonisation, la perturbation, l'environnement physique, les interactions inter- et intra-communautés, et la dynamique de ces communautés. Des occasions de développer des stratégies de gestion des communautés de mauvaises herbes existent à l'intérieur de chacun de ces éléments. Si la diversité pouvait être gérée tout en maintenant des rendements acceptables, certains bénéfices découlant de la présence des mauvaises herbes et non encore considérés pourraient être observés, tel que le prédisent les relations existant entre les plantes de communautés non gérées. De plus, l'objectif d'obtenir un système de production plus durable, tenant compte de la diversité des communautés de mauvaises herbes, pourrait être accompagné d'orientations vers une politique encourageant la biodiversité des agro-écosystèmes.
Ce document est protégé par la loi sur le droit d'auteur. L’utilisation des services d’Érudit (y compris la reproduction) est assujettie à sa politique d'utilisation que vous pouvez consulter en ligne.

https://apropos.erudit.org/fr/usagers/politique-dutilisation/ 
Review article / Article de synthèse

\title{
Integrated weed management and weed species diversity
}

\author{
David R. Clements, Stephan F. Weise, and Clarence J. Swanton ${ }^{1}$
}

Received 1993-08-06; accepted 1994-01-25

\begin{abstract}
Alternative practices for weed management, such as integrated weed management (IWM) may allow the persistence of weed populations below a given economic threshold. Increased species diversity of weeds also may result. If diversity increases, and the number of ecological interactions also increases, weed species should be viewed as an interactive community, rather than an unrelated set of targets for control. In this review we summarize how diversity is evaluated in unmanaged systems, examine how IWM techniques may alter the diversity of weed species and suggest how strategies can be developed for managing weed diversity under IWM. Methods used to evaluate diversity in natural systems may be used to evaluate weed diversity in alternative systems of weed management. We made preliminary calculations of diversity for reduced tillage, modified herbicide use, crop rotation, critical period of weed control, techniques to improve crop competitiveness, and alternative control methods. Many of these IWM techniques potentially may result in changes in weed species diversity. We examined potential effects of these changes in weed diversity within six primary elements of community ecology: colonization, disturbance, the physical environment, interactions with other communities, community interactions and community dynamics. Opportunities to develop strategies of community management exist within each of these elements. If diversity could be managed while maintaining acceptable crop yields, some previously unrealized benefits of the presence of weeds could be seen, as predicted by relationships among plants of unmanaged communities. Moreover, the goal of producing a more sustainable system that incorporates the diversity of the weed community would be complemented by trends in policy towards encouraging biodiversity in agroecosystems.
\end{abstract}

Clements, D.R., S.F. Weise et C.J. Swanton. 1994. Gestion intégrée des mauvaises herbes et diversité des espèces. PHYTOPROTECTION 75: 1-18.

Les méthodes alternatives de gestion des mauvaises herbes, telles que la gestion intégrée, peuvent permettre la persistance de populations de mauvaises herbes sous un seuil économique déterminé. Une diversité accrue des espèces de mauvaises herbes peut aussi en résulter. Si la diversité ainsi que le nombre d'interactions écologiques augmentent, les espèces de mauvaises herbes devraient être considérées comme une communauté interactive plutôt que comme un ensemble disparate de cibles contre lesquelles lutter. Cet article de synthèse résume les méthodes d'évaluation de la diversité dans des systèmes non gérés, examine comment les techniques de gestion intégrée

1. Department of Crop Science, University of Guelph, Guelph, Ontario, Canada N1G 2W1 
peuvent modifier la diversité des espèces de mauvaises herbes, et finalement, suggère des façons de développer des stratégies pour gérer la diversité des mauvaises herbes par la gestion intégrée de celles-ci. Les méthodes utilisées pour évaluer la diversité dans les systèmes naturels peuvent servir à évaluer la diversité des mauvaises herbes dans des systèmes alternatifs de gestion intégrée. Nous avons effectué des calculs préliminaires de diversité pour le labour réduit, l'utilisation modifiée des herbicides, les rotations culturales, la période critique d'intervention contre les mauvaises herbes, les techniques d'amélioration de la compétitivité des cultures et les méthodes de lutte alternatives. Plusieurs de ces techniques de gestion intégrée peuvent éventuellement résulter en des modifications de la diversité des espèces de mauvaises herbes. Nous avons examiné les effets potentiels de ces changements sur la diversité des mauvaises herbes à l'intérieur de six principaux éléments de l'écologie des communautés: la colonisation, la perturbation, l'environnement physique, les interactions inter- et intra-communautés, et la dynamique de ces communautés. Des occasions de développer des stratégies de gestion des communautés de mauvaises herbes existent à l'intérieur de chacun de ces éléments. Si la diversité pouvait être gérée tout en maintenant des rendernents acceptables, certains bénéfices découlant de la présence des mauvaises herbes et non encore considérés pourraient être observés, tel que le prédisent les relations existant entre les plantes de communautés non gérées. De plus, l'objectif d'obtenir un système de production plus durable, tenant compte de la diversité des communautés de mauvaises herbes, pourrait être accompagné d'orientations vers une politique encourageant la biodiversité des agroécosystèmes.

\section{INTRODUCTION}

Currently there are strong environmental and economic incentives for adopting alternative practices for weed management, such as integrated weed management (IWM) (Pannell 1990; Swanton and Weise 1991). Integrated weed management may provide a more sustainable approach to crop production, reducing the reliance on external inputs that characterizes conventional agriculture. One goal of IWM is to maintain weed populations below an economic threshold level (Auld and Tisdell 1987; Swanton and Weise 1991). Management to achieve this goal reduces emphasis on strategies of eradication or prophylaxis and promotes a strategy of containment (Cousens 1987). Thus, IWM must incorporate a containment strategy for potential increases in weed diversity, because of increased survival of existing species or colonization by new species.

Ecologists have studied the subject of diversity extensively in unmanaged systems (Brown 1981; Kolosa and
Strayer 1988; MacArthur 1972; Magurran 1988; Silvertown and Dale 1991). It would be valuable to link ecological theory of community diversity with potential changes in weed diversity under IWM and to develop a management approach that would view weeds as a community rather than as individual species. Weeds of intensively managed crops have been studied mostly at the species level, and thus there is relatively little information available on the impact of weed diversity on weed management. In this review we summarize how diversity is evaluated in unmanaged systems, examine how IWM techniques may alter the diversity of weed species and suggest how strategies can be developed for managing weed diversity under IWM.

\section{EVALUATING DIVERSITY IN NATURAL SYSTEMS}

\section{Definitions and measures}

There are a number of key terms used in the discussion of diversity in ecology (Table 1). Species diversity, in terms of 
species richness, is measured as the number of species in a community. Diversity could also be measured within species (e.g. different weed biotypes) but this paper primarily deals with diversity among species. Two communities with an identical number of species can differ in terms of evenness, and hence it is also useful to know the proportional or relative abundance of species within the community (Magurran 1988). If a community is dominated by one or two species, it can be said to be less diverse than a community with an equal number of species with a more equitable distribution of population sizes.

Table 1. Definitions of important terms used in discussing ecological diversity (Begon et al. 1990; Magurran 1988; Pimm 1984; Walker 1989)

\begin{tabular}{ll}
\hline Term & \multicolumn{1}{c}{ Definition } \\
\hline Community & The species that occur together in space and time \\
Diversity & $\begin{array}{l}\text { The number of species within a community, or more generally, } \\
\text { the degree of variation within the community (i.e. diversity can } \\
\text { vary between communities with the same number of species } \\
\text { due to differences in relative abundance) }\end{array}$
\end{tabular}

Relative abundance

Species richness

Species evenness

Species dominance

Stability

Community structure

Complexity

Connectivity

Compartmentalization

Guild structure

$\mathrm{K}$ and $\mathrm{r}$ strategies

Niche differentiation
The population of a species expressed in proportion to the other species within the community

The number of species present

The degree to which different species present tend to have the same relative abundance

The degree to which one or a few species tend to occur more abundantly than the others

The tendency of a community to return to its original state following a disturbance

The organization of the community as determined by the relative abundance of species

The number of connections among organisms in the community

The degree to which species are linked by interspecific interactions

The division of communities into groups of species that have distinctly more interactions amongst themselves than with the community as a whole

The division of communities into groups of species that share similar ecological roles

Plants with $\mathrm{K}$ strategies are adapted to long-term persistence in stable environments, and have low population growth rates, whereas plants with $r$ strategies can rapidly reproduce in disturbed environments

The ability of different species to occupy the same environment through differences in their resource requirements 
Indices have been developed to combine species richness with proportional abundance within a single value. Examples include the Shannon index, the Simpson index and $\alpha$ of the log series (Magurran 1988). As yet, no one index has been adopted as the most appropriate or practical index, and the choice may depend on the data set (Magurran 1988). In particular, it is important to account for the biases towards species richness, evenness or dominance (Magurran 1988). These biases reflect the difficulty inherent in combining species richness and relative abundance into a single parameter.

Weed research has also employed synthetic importance values that attempt to account for the patchiness of weed abundance and sampling error (Conn and Delapp 1983; Thomas 1985; Wentworth et al. 1984). This may be useful when ordering species by abundance in studies of weed diversity. For example, Thomas (1985) computed relative abundance by combining frequency, density and uniformity into a single abundance value, with uniformity calculated from the number of quadrats containing a given species expressed as a percentage of the total number of surveyed quadrats. The advantage of synthetic importance values is to provide a single parameter that provides a comprehensive measure of abundance by including considerations of scale and sampling (Thomas and Ivany 1990). However, such values lose some of the information contained in the data used to derive them.

The community structure (i.e. patterns of relative abundance) of plant communities and its relation to other factors may also be analyzed by multivariate techniques. Use of techniques such as principle component analysis (PCA) or canonical discriminant analysis (CDA) may in some instances overcome difficulties inherent in univariate analyses of weed communities (Brain and Cousens 1990; Cousens 1988; Hughes 1990). Multivariate techniques permit the analyses of communities as a whole because unlike univariate techniques, weed species of low occurrence are readily incorporated in the analysis. Thus, the structure of the entire community can be accounted for, without frequency or density biases towards certain species. However, sometimes these biases are real and must be considered as part of the analysis.

\section{Theory}

Simply measuring the diversity of a community is not directly meaningful; for theories to be developed and tested, diversity must be related to ecosystem processes and properties (MacArthur 1972). Investigations of species diversity within theoretical ecology primarily have involved relationships between diversity and area, relative abundance patterns, and relationships between diversity and stability (Magurran 1988). Knowledge of diversity-area relationships is useful in accounting for the spatial scale at which diversity is evaluated (Lepš and Stursa 1989). Attempts have been made to relate mathematical distributions of relative abundance patterns to niche differentiation or habitat patchiness (Kolosa and Strayer 1988; Sugihara 1980). Regardless of the mathematical distribution, relative abundance curves (i.e. cumulative relative abundance plotted against species) are useful indicators of dominance-diversity relationships (Whittaker 1965).

Relationships between diversity and stability have received attention from both theoretical and applied biologists. Although the idea of higher species diversity leading to higher stability has intuitive appeal (Elton 1958; Kikkawa 1986; Magurran 1988), there are other aspects to consider. One important aspect frequently considered is the complexity of the community (Table 1), which consists of the number of ecological connections among organisms in the community (Kikkawa 1986). Conceptually, the interaction strength of these connections (May 1972) may be difficult to apply to plant communities where all species are at the same trophic level (Gitay and Agnew 1989). Compartmentalization is also important; a simple ecosystem may consist of a single food web involving all organisms present, whereas more complex ecosystems may consist of numerous compartments, with a high degree of connectivity within, but not between compartments. 
The time element is also important (Walker 1989) because relationships among species in a community may or may not have had enough time to attain stability. Once a community becomes stable, diversity may decline below levels found during earlier successional stages, forming a "humpback" profile of diversity over time (Connell 1978; Gibson and Brown 1991; Grime 1973; Odum 1963, 1969). The higher diversity at intermediate levels of disturbance likely results from a trade-off between the competitive ability of plants and their ability to withstand disturbance (Petraitis et al. 1989). At intermediate levels, more species may survive than at higher levels of disturbance, and competitive ability may be less important than at lower levels of disturbance.

Evidence against the diversity-stability hypothesis includes theoretical models, based on random connectivity among species, that predict lower stability with greater diversity (May 1971, 1972, 1973). However, connections among species developed over time are not random and may be based on a variety of complex ecological factors. Connections favouring stability are formed through guild structure development, $\mathrm{K}$ and $\mathrm{r}$ strategies, compartmentalization of trophic structure, niche differentiation, and ecological succession (Gitay and Agnew 1989; Kikkawa 1986; Murdoch 1975; Pianka 1980)(see Table 1 for definitions). The concept of diversity leading to stability does not form a general principle for all ecosystems (Goodman 1975; Walker 1989). A detailed knowledge of the interrelationships, together with actual measurements of stability, are necessary to define the relationship between diversity and stability for a given ecosystem (Murdoch 1975; Woolhouse and Harmsen 1987). Furthermore, stability is not the sole criterion for success in pest management, because a stable system does not ensure pest suppression below an economic threshold level (Andow 1991; Murdoch 1975).

The ecology of species diversity has been studied for many communities including coral reefs (Connell 1978), tropical rain forests (Connell 1978), grasslands (Chaneton and Facelli 1991; Gitay and Agnew 1989), meadows (Kull and Zobel 1991), old fields (Gibson and Brown 1991), and agricultural communities (Mclntyre et al. 1991). However, because suppression of both weed density and diversity has been sought within agricultural systems, little effort has been devoted to the study of diversity within agricultural weed communities. Weed species generally have been studied as an unrelated set of targets for weed control, rather than as ecological communities. In the following section we compare the diversity and stability of agricultural communities with natural communities, and discuss the potential influences of alternative practices employed under IWM on the diversity of weed communities.

\section{DIVERSITY OF WEED COMMUNITIES UNDER IWM}

Before considering the potential role of IWM in modifying weed diversity, we must first discuss the general issue of diversity in agriculture. The decrease in diversity associated with growing crops in monocultures has been cited as an important source of instability in agricultural communities (Elton 1958; Odum 1969), but there are other possible reasons for the instability of agricultural systems in comparison to natural systems (Murdoch 1975; Pimm 1984). Possible reasons for the relative instability of agricultural communities include lower structural and spatial diversity, higher levels of disturbance, lower successional maturity, lack of coevolution among biotic constituents and taxonomic composition (Murdoch 1975; Pickett and Bazzaz 1978; van Emden and Williams 1974; Woolhouse and Harmsen 1987). In particular, the high levels of disturbance caused by pesticide use can lead to outbreaks in pest populations, if pests become resistant or natural enemies are disrupted. Although the rules governing the dynamics of cropping systems and natural systems do not correspond directly (Murdoch 1975), it is useful to compare features of agricultural and natural systems in the pursuit of more ecological approaches to pest management. Certain natural systems, such as 
early successional communities, have much in common with artificially disrupted agroecosystems (Pickett and Bazzaz 1978).

As well as being species-poor relative to other communities of herbaceous plants (Hodgson 1986), agricultural weed communities are fairly uniform throughout the temperate regions (Pyšek and Lepš 1991). The number of weed species within geographic regions is quite low. Several species tend to dominate (Mclntyre et al. 1991), with the remainder present at densities too low to have major impacts on the crop.

When agronomic practices undergo long-term changes, fundamental changes in weed communities may occur (Mahn 1984). Surveys have linked agronomic practices to differences in weed diversity (Hidalgo et al. 1990; Pyšek and Lepš 1991; Salonen 1989; Shaltout and El Fahar 1991; Thomas and Ivany 1990). Characteristics of weeds, such as short life cycles, seed dormancy, plasticity, colonization ability and high reproductive rate, facilitate rapid turnover of communities (Gibson and Brown 1991; Grime 1979; Pickett and Bazzaz 1978; Radosevich and Holt 1984; Shaltout and El Fahar 1991; Thompson and Grime 1979). At present, many alternative management practices are under consideration (Swanton and Weise 1991), which, if adopted on a large scale, may alter the structure and diversity and perhaps even the stability of weed communities. A better understanding of these potential changes is necessary to facilitate a reasonably efficient transition from conventional to alternative management approaches such as IWM.

Preliminary comparisons of diversity under alternative management practices with diversity under conventional practices are presented in Table 2. These comparisons are selected cases where there was a large difference in density between alternative and conventional treatments. When control measures are integrated under IWM, the composition of the resulting weed community results from the trade-offs among various management practices. Nevertheless, it is useful to look at the potential impacts of each practice on weed diversity.
Species richness was increased as density increased with reduced tillage, banded herbicides, nitrogen management (more precise rates and fertilizer placement) and cultivation (Table 2). By comparison to preemergence herbicides (residual), applications of postemergence (non-residual) herbicides reduced species richness less (species richness was reduced from 28 to 25 by postemergence herbicides, and from 9 to 3 by preemergence herbicides). Although a critical period of weed control decreased species richness in relation to a season-long weedy treatment, the reverse would be true for a comparison for season-long weed control. Species richness decreased with decreased weed density for crop rotation with fallow, use of competitive cultivars, higher density planting and the use of cover crops. Thus, IWM techniques do not promote increased species richness consistently, but there are good indications (Table 2) that increases or decreases in weed density may be accompanied by changes in weed species richness.

The diversity indices generally concurred with the trends in species richness (Table 2), particularly the Shannon diversity index, which is biassed toward species richness (Magurran 1988). Hovvever, in some cases the community structure did not differ greatly between treatments in terms of relative abundance. Simpson's diversity index was very similar between tillage methods for aboveground weeds, and between cultivars of different competitiveness, indicating that the relative abundance of the more common species was fairly constant. Conversely, although there was only a slight difference in species richness between nutrient management treatments, both diversity indices indicated a strong trend toward greater diversity in relative abundance with a lower nutrient input. Although cover crops reduced species richness, they increased Simpson's diversity. This increase was the result of increased equitability when weed clensity was reduced. The bare soil treatments were dominated by one or two species. More detailed analyses are neecled to better understand trends in relative abundance under IWM, and interpret their significance for the management of weed communities. 
Table 2. Comparison of standard and alternative weed management practices employed under integrated weed management (IWM) and their impacts on weed density and diversity

\begin{tabular}{|c|c|c|c|c|c|}
\hline Management practice & $\begin{array}{c}\text { Weed } \\
\text { density } \\
\left(\mathrm{m}^{-2}\right)\end{array}$ & $\begin{array}{c}\text { Species } \\
\text { richness } \\
\qquad(S)^{\mathrm{a}}\end{array}$ & $\begin{array}{c}\text { Shannon } \\
\text { diversity } \\
(H)^{\mathrm{a}}\end{array}$ & $\begin{array}{c}\text { Simpson's } \\
\text { diversity } \\
(D)^{\mathrm{a}}\end{array}$ & Source \\
\hline \multicolumn{6}{|l|}{$\begin{array}{l}\text { Reduced tillage: } \\
\text { Conventional tillage }\end{array}$} \\
\hline weed seeds & 2233 & 3.9 & 0.70 & 0.20 & \multirow{2}{*}{$\begin{array}{l}\text { Cardina et al. } \\
(1991)\end{array}$} \\
\hline No-till weed seeds & 29433 & 7.6 & 1.20 & 0.50 & \\
\hline Conventional tillage weeds & 16 & 18.7 & 0.97 & 0.86 & \multirow[t]{2}{*}{ Derksen (1991) } \\
\hline No-till weeds & 30 & 22.0 & 1.31 & 0.87 & \\
\hline \multicolumn{6}{|l|}{ Herbicide use: } \\
\hline Broadcast herbicide & 8 & 11.8 & 0.70 & 0.65 & \multirow{2}{*}{$\begin{array}{l}\text { Swanton } \\
\text { (unpublished data) }\end{array}$} \\
\hline Banded (with cultivation) & 14 & 14.0 & 0.87 & 0.81 & \\
\hline \multicolumn{6}{|l|}{ Before postemergence } \\
\hline application & 444 & 28.0 & 0.86 & 0.80 & \multirow{2}{*}{ Derksen (1991) } \\
\hline $\begin{array}{l}\text { Arter postemergence } \\
\text { application }\end{array}$ & 34 & 25.0 & & & \\
\hline \multicolumn{6}{|l|}{ Without preemergence } \\
\hline With preemergence & 12 & 3.0 & 0.29 & 0.35 & \multirow{2}{*}{$\begin{array}{l}\text { Swanton } \\
\text { (unpublished data })^{\circ}\end{array}$} \\
\hline application & & & & & \\
\hline \multicolumn{6}{|l|}{ Crop rotation: } \\
\hline Continuous cropping ${ }^{d}$ & 22 & 16.7 & 1.03 & 0.88 & \multirow[t]{2}{*}{ Derksen (1991) } \\
\hline Rotation with fallow & 12 & 14.0 & 0.79 & 0.77 & \\
\hline \multicolumn{6}{|l|}{ Critical period: } \\
\hline Season-long weedy & 230 & 5.0 & 0.59 & 0.71 & \multirow[t]{2}{*}{ Van Acker (1992) } \\
\hline $\begin{array}{l}\text { Minimum weed-free } \\
\text { (to prevent } 25 \% \text { vield loss) }\end{array}$ & 3 & 3.0 & 0.41 & 0.56 & \\
\hline \multicolumn{6}{|l|}{ Crop competitiveness: } \\
\hline Least competitive cultivar & 171 & 9.0 & 0.68 & 0.73 & \multirow{2}{*}{$\begin{array}{l}\text { Weise } \\
\text { (unpublished data) }\end{array}$} \\
\hline Most competitive cultivar & 81 & 6.7 & 0.66 & 0.74 & \\
\hline Low density planting & 73 & 10.5 & 0.71 & 0.71 & \multirow[t]{2}{*}{ Dibo (1991) } \\
\hline High density planting & 58 & 10.0 & 0.68 & 0.73 & \\
\hline High nitrogen treatment & 59 & 12.0 & 0.75 & 0.75 & \multirow[t]{2}{*}{ Nissanka (1991) } \\
\hline Low nitrogen treatment & 68 & 13.2 & 0.91 & 0.85 & \\
\hline \multicolumn{6}{|l|}{ Alternative control methods: } \\
\hline No cover crop & 91 & 6.0 & 0.30 & 0.39 & \multirow[t]{2}{*}{ Moore (1992) } \\
\hline Cover crop & 26 & 2.7 & 0.34 & 0.52 & \\
\hline Broadcast herbicide & 8 & 11.8 & 0.70 & 0.65 & Swanton \\
\hline Cultivation only & 34 & 16.3 & 0.83 & 0.80 & (unpublished data) $^{\mathrm{b}}$ \\
\hline
\end{tabular}

a $S=$ number of species; $H=-\sum\left(p_{i}\right)\left(\log p_{i}\right) ; \quad D=\sum\left(p_{i}^{2}\right)$;

$p_{i}$ is the proportion of the sample belonging to the $i^{\text {th }}$ species; indices are calculated by summing the expressions for the total number of species in the sample.

b Data from weeds growing in no-till soybeans and corn in 1991 and 1992 at the Woodstock Research Station, Woodstock, Ontario.

c Data from weeds growing in corn in 1989 at a demonstration site near Fingal, Ontario. The preemergence herbicide combination was cyanazine + metolachlor.

d Crop sequences including wheat, flax, canola and barley.

e Data from weeds growing in soybeans at the Woodstock Research Station, Woodstock, Ontario in 1990. 
Efforts to expand on the preliminary analysis presented in Table 2 would involve surveys and field studies, and calculating diversity indices (Cardina et al. 1991; Mahn 1984; Topham and Lawson 1982), synthetic importance values (Frick and Thomas 1992; Thomas 1985; Thomas and Ivany 1990) and multivariate statistics (Conn and Delapp 1983; Derksen et al. 1993; Hume 1982, 1987; Mesléard et al. 1991; Mohler and Liebman 1987; Pyšek and Lepš 1991; Wentworth et al. 1984). Given the importance of weed distribution (Brain and Cousens 1990), it also would be useful to compare weed patchiness between conventional and alternative systems. There may be spatial differences in terms of germination and establishment with varying levels of disturbance that influence pattern diversity (Pielou 1966; Scheiner 1992). However, a preliminary look at the effects of IWM practices on diversity (Table 2) reveals that in some cases, species richness and community structure may be altered appreciably, and may have implications for management.

\section{MANAGEMENT OF WEED DIVERSITY}

A number of elements influence cornmunities (Fig. 1). Important elements include colonization (Noss 1990), disturbance (Petraitis et al. 1989; Pickett et al. 1987), the physical environment (Brown 1981; Tilman 1982), and interactions with organisms of other communities (Gibson and Brown 1991).

The elements that structure communities can be linked to the development of IWM, as indicated by the key exarnples listed in parentheses in Figure 1. In the case of colonization, new weed management methods may permit the establishment of weeds with reproductive strategies not previously encountered (Swanton et al. 1993). Modifications in the degree of disturbance can be related to changes in tillage practices and herbicide applications. Changes in the physical environment under IWM may include fertilizer placement proximal to the crop or increasing organic matter content of

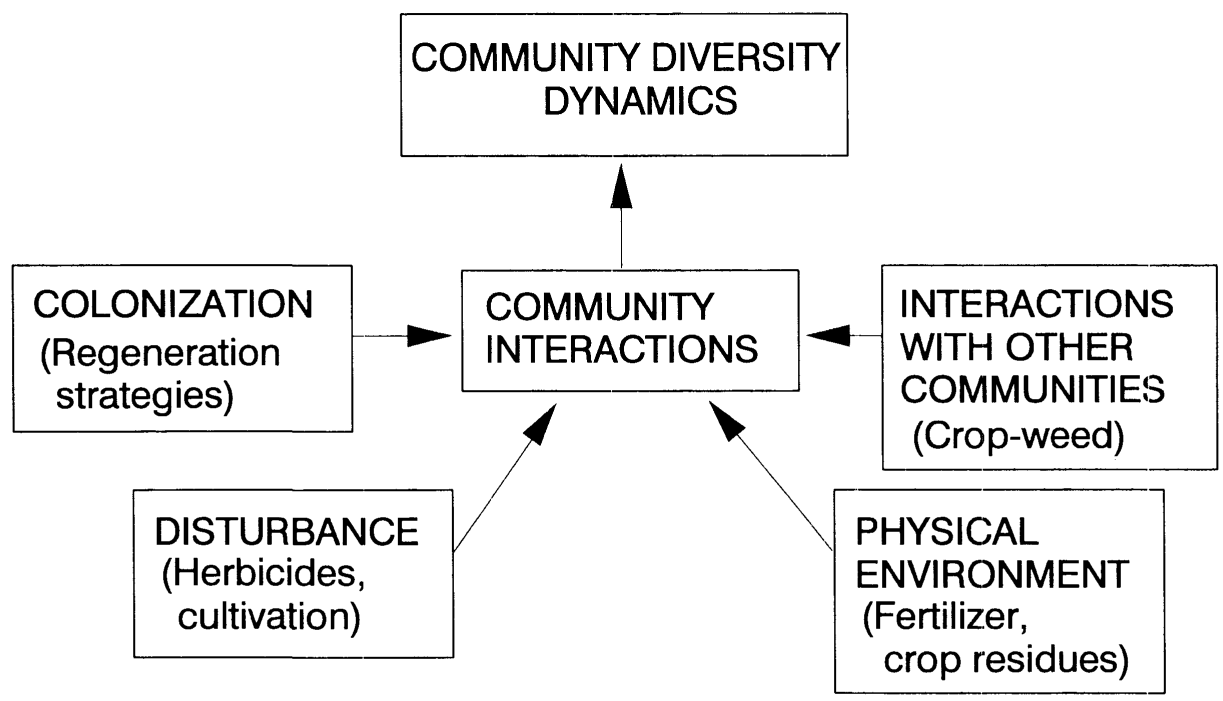

Figure 1. Interactions among environmental factors impacting community interactions. Key examples of links between these factors and changing weed management practices in agricultural systems are given in parentheses. 
the soil in reduced tillage (Swanton and Weise 1991). Interactions with other communities in alternative weed management systems encompass a wide spectrum of communities such as weed seed predators (Brust and House 1988), mycorrhizae (McGonigle et al. 1990) or pathogenic fungi (Ayres and Paul 1990), but the crop community (or monoculture) is of fundamental importance in influencing weed community interactions (Swanton and Weise 1991).

Diversity and community dynamics are the result of numerous interactions between factors intrinsic and extrinsic to the community (Chaneton and Facelli 1991; Connell 1978; Maurer 1987; Noss 1990; Pimm 1984), and so it is important to account for all possible factors pertaining to the ecosystem under study. This may be especially true for agroecosystems, where nearly all ecological factors are subject to agronomic manipulation. Implications of weed diversity for management and research are discussed below within the context of colonization, disturbance, physical environment, interactions with other communities, community interactions and community dynamics (Fig. 1; Table 3). As previously outlined, these categories relate to major elements that influence communities (Begon et al. 1990), but it should also be recognized that these elements also influence one another, such that the boundaries between categories are often blurred.

\section{Colonization}

Changes in the environment under IWM may promote colonization by weeds from other areas that were not previously associated with conventional cropping systems. Reduction in disturbance through adoption of IWM techniques, such as reduced tillage and reduced herbicide use, tends to provide safe sites (Sagar and Harper 1961) for weed germination and establishment not present in more conventional systems. An example is the colonization of Bromus tectorum $\mathrm{L}$. of fields in southwestern Saskatchewan in response to a reduction in tillage, lack of effective herbicides, and weather conditions favouring autumn germination and early spring competition (Douglas et al. 1990).

Reduced tillage reduces disturbance and potentially allows colonization of species adapted to the modified environment (Swanton et al. 1993). Changes in

Table 3. Implications of increased diversity, in terms of factors affecting weed communities and their management under integrated weed management (IWM)

\begin{tabular}{|c|c|c|}
\hline \multirow[b]{2}{*}{ Factor } & \multicolumn{2}{|c|}{ Implications of increased diversity } \\
\hline & Weed community & Weed management \\
\hline Colonization & Increased variety of weed species & $\begin{array}{l}\text { Adjustment to differences in life } \\
\text { history, competitiveness }\end{array}$ \\
\hline Disturbance & More varied weed life histories & $\begin{array}{l}\text { Reconsideration of control } \\
\text { techniques, strategies }\end{array}$ \\
\hline $\begin{array}{l}\text { Physical } \\
\text { environment }\end{array}$ & Changed resource utilization patterns & $\begin{array}{l}\text { Manipulation of resources to } \\
\text { favour the crop }\end{array}$ \\
\hline $\begin{array}{l}\text { Interactions } \\
\text { with other } \\
\text { communities }\end{array}$ & Increased stress on weeds & $\begin{array}{l}\text { Manipulation of stresses to } \\
\text { minimize impacts of weeds on } \\
\text { crops }\end{array}$ \\
\hline $\begin{array}{l}\text { Community } \\
\text { interactions }\end{array}$ & Increased weed-weed interactions & $\begin{array}{l}\text { Economic thresholds adjusted } \\
\text { for interactions within weed } \\
\text { communities }\end{array}$ \\
\hline $\begin{array}{l}\text { Community } \\
\text { dynamics }\end{array}$ & $\begin{array}{l}\text { Improved chance of greater } \\
\text { community stability }\end{array}$ & $\begin{array}{l}\text { IWM systems designed to } \\
\text { produce optimal community } \\
\text { structure }\end{array}$ \\
\hline
\end{tabular}


community structure may involve a larger proportion of grass species, winddisseminated species or perennials (Froud-Williams 1988). Weed species contributing to increases in diversity in Table 2 included Hordeum jubatum L. and Bromus inermis Leyss. (Derksen 1991); and Stellaria media L. Cyrill., Lamium amplexicaule L., Panicum capillare L. and Abutilon theophrasti Medic. (Cardina et al. 1991).

If season-long weed control is replaced by control during a critical period (Hall et al. 1992; Van Acker et al. 1993; Weaver 1984; Woolley et al. 1993), weeds may colonize during times when weed control is unnecessary. Responses to a critical period of weed control would be expected to vary among weed species, based on timing and duration of emergence. Van Acker (1992; Table 2) observed that Sinapis arvensis L., Erysimum cheiranthoides L., and Setaria glauca (L.) Beauv. failed to emerge after the critical period, and this was responsible for the lower species richness than in the season-long weedy treatment. Postemergence weed control strategies may favour higher diversity because of the early emergence times of many weed species. Van Acker (1992) found that the maximum species richness was frequently attained as early as the first development stage of soybeans.

The implication of colonization for the weed community is the potential for a gradual introduction of a greater variety of reproductive strategies and life histories (Table 3; Grime 1979). The implication for management is that adjustments would have to be made according to the life histories and competitiveness of weed species adapted to the new disturbance regime (Table 3). Superficially, an increase in the variety of weed life histories may appear to be a serious threat to crop production. Weed management strategies generally have attempted to minimize the number of distinct types of weed problems. However, many of the newly encountered or minor weeds may be less competitive. Furthermore, management can manipulate colonization itself (Maxwell and Ghersa 1992), and this may be especially crucial for species that are inherently good invaders (Barrett 1992).

\section{Disturbance}

As mentioned with respect to colonization, the nature of agricultural disturbances changes under IWM with nodifications in tillage, herbicide use or other practices. These modifications potentially favour different weed life histories, even among weed species already occupying land that is converted to IWM. Thus, even if new species do not colonize an area, there may be shifts in the relative abundance patterns. The implication for management is that control strategies must be reconsidered (Table 3 ).

Reduced disturbance via reduced primary tillage generally has been thought to produce shifts in species composition (Froud-Williams 1988; Hinkle 1983; Koskinen and McWhorter 1986), although management moderates these potential shifts (Swanton et al. 1993). Management should constitute some form of "succession management", and use "designed disturbance" to determine the resultant community structure (Luken 1990). Reconsideration of control strategies (Table 3) may require assessing the life history strategies most likely to succeed under reduced tillage and developing strategies to restrict populations of these weeds. Additionally, the system of conservation tillage that results in the most manageable weed community should be identified.

Cultivation for the purpose of weed control within the established crop (e.g. inter-row cultivation) is an important form of disturbance among IWM systems. Cultivation may be substituted for herbicide use or used in conjunction with banding of herbicides. Cultivation alone, in comparison to broadcast herbicide treatments, resulted in higher weed density and diversity (Table 2). In at least two of four crop-year combinations, Echinochloa crusgalli (L.) Beauv., Oxalis stricta L., Digitaria sanguinalis (L.) Scop., Chenopodium album L., Cirsium arvense (L.) Scop., Setaria viridis (L.) Beauv. and Amaranthus retroflexus $L$. were found in the cultivation treatment but not in plots with herbicidal control. A closer examination of these species would be required to determine whether they possess any specific adaptations to mechanical control. 
Reduction in disturbance through reduced herbicide use in IWM (Swanton and Weise 1991) has important consequences for weed communities, particularly if species new to a given field become established. Banding of herbicides allowed two additional weed species to survive in the study referred to in Table 2. Weeds have a wide range of strategies for tolerating herbicides, and some, such as postharvest growth and development (Hume 1988), may be enhanced if non-residuals are used in place of residual herbicides. The tendency toward increased diversity caused by reduced rates and non-residual herbicides (Table 2) may be compensated for by the increased use of tank mixes to provide more broad spectrum control (Martin 1987). However, even the most intensive use of herbicides tends to alter proportional abundance rather than eliminate weeds (Chancellor 1979; Hume 1987). Although herbicides reduce the populations of target weeds, non-susceptible weed species may exhibit compensatory increases in abundance (Evetts and Burnside 1975; Harper 1957; Holzner 1978). Detailed examinations of the effects of modified herbicide use on community structure are needed.

Diversity may provide a buffer against the development of herbicide resistance. If single-species outbreaks are prevented, there will be less opportunity for resistant genes to be propagated. Greater diversity within weed species may also prevent the proliferation of resistant biotypes. Re-evaluation of techniques and strategies for herbicide use should consider particular concerns regarding specific species while at the same time developing strategies for the entire community. Some species need to be kept at extremely low populations to minimize seed production and promote long-term control (Légère and Deschênes 1989; Norris 1992; Zanin and Sattin 1988). Alternatively, threshold management may be sufficient to maintain acceptable control of many weed species under optimal conditions (Cousens 1987; Jordan 1992; Swanton and Weise 1991). A community management strategy should develop a threshold for herbicide use based on the entire weed spectrum present, rather than only on certain species.

\section{Physical environment}

Developing an IWM system to produce yields comparable to more conventional systems involves redesigning the crop production system (Swanton and Weise 1991), including both fertility management and tillage (Fig. 1). Thus, a very different physical environment results from changing the disturbance regime, as discussed in the previous two sections on colonization and disturbance. These physical influences should be modified to provide favourable growing conditions for the crop, while discouraging weed growth (Table 3). Fertilizer placement in close proximity to the crop is one such selective mechanism, designed to fertilize the crop but not the weeds (Swanton and Weise 1991). However, Nissanka (1991) found that low levels of nitrogen actually produced higher weed density (Table 2), likely because competition with the crop was reduced at low nitrogen levels. An awareness of the nitrogen requirements of particular weed species would facilitate the design of fertilizer management systems that do not promote the more competitive members of weed communities.

The reduction in soil disturbance due to conservation tillage causes a complex series of changes in the soil environment. Three primary effects are reduction in soil mixing, greater retention of water, and increased bulk density. All of these may promote a wide range of changes in the soil that interact to produce a soil environment very different than that found under conventional tillage. The increased biological activity of the soil is the result of many interacting factors such as the presence of organic matter from crop residues, increased soil moisture and increased microporosity (Froud-Williams et al. 1983; Unger 1984). This increased biological activity is evident within the detritus food web (Hendrix et al. 1986). Furthermore, the diversity and number of birds (Basore et al. 1986; Duebbert and Kantrud 1987), mammals (Rodgers and Wooley 1983; Warburton and Klimstra 1984), arthropods (Blumberg and Crossley 1983; House and Parmelee 1985), earthworms and other soil fauna (House and Brust 1989; Parmelee et al. 1990) on conservation tillage land often is greater than on conventionally tilled land. These 
changes in fauna likely would have implications in the composition of weed species through successional changes (McBrien et al. 1983).

Other, more subtle, changes in the physical environment may also occur in response to changes under IWM, including changes due to the effects of reduced pesticide loading, and the effects of changing community interactions and dynamics, as discussed below.

\section{Interactions with other communities}

A sparse weed community would be less likely to form many connections with other communities than a more diverse one. If a more diverse community interacts more with other communities, many of these interactions could cause stress to the weeds present (Table 3 ). If these stresses can be manipulated, they could be used to the advantage of weed management. Of the communities that interact with the weed community in a typical agroecosystem, two communities of interest are the crop and herbivore communities, as discussed below.

A central issue is whether or not an increased diversity of weed species, at the same weed density, would have a reduced effect on crop yield. Mohler and Liebman (1987) found that because the dominant weed was competitively inhibited by the crop as crop productivity increased, the most dominant weed species was more suppressed than other species. Breeding programs are producing crops with greater competitive ability (Haas and Streibig 1982), through changes in growth patterns and canopy structure. Given the potential influence of crop competitiveness on weed diversity (Table 2), it may be useful to make detailed studies of the interactions between weed diversity and the crop.

Experimental approaches could involve planting different species assemblages and applying different levels of weed control. The influences of more diverse life histories and resource allocation strategies could be evaluated. Such approaches would be quite complex, but could take advantage of recent innova- tions in the study of plant competition (Aldrich 1987; Beyrouty and Oosterhuis 1989; Pacala and Silander 1987; Radosevich 1987).

Although the crop community is generally fairly monotonic, diversity is introduced in the form of crop rotation, cover crops and other more complex cropping systems. Crop rotation produces a greater variety of weed-crop competitive relationships (Harper 1957; Heatherly et al. 1990). Weed density is generally reduced, because problem weeds associated with a particular crop do not have a chance to build up populations in succeeding years, and because herbicides are also rotated (Bullock 1992). This reduced weed density within years may be associated with a reduction in diversity (Table 2), although higher diversity across the rotation may also be predicted on the basis of multiple weed-crop associations (Slife 1981). Derksen (1991) found that several species were associated with continuous cropping in western Canada, whereas only Matricaria matricarioides (Less.) Porter was associated with a crop-fallow rotation.

Moore (1992) observed that cover crops reduced weed species richness (Table 2). Four weed species: Polygonum convolvulus $L ., P$. aviculare L., Sinapis arvensis and Amaranthus retroflexus were found exclusively in bare soil treatments. However, as previously discussed, Simpson's diversity was higher in association with cover crops, such that abundances of the fewer species were distributed more equitably. Thus, the use of cover crops may be a good technique for reducing populations of competitive weed species adapted to highly disturbed environments.

Herbivory on weeds has been compared in conservation versus conventional tillage systems (Blumberg and Crossley 1983; Brust and House 1988; House and Brust 1989), and in diverse versus monotonic communities (Altieri and Letourneau 1982; Andow 1991; Andres 1982). A positive correlation was observed between increased diversity and the effectiveness of biological control of weeds and other pests (Altieri and Letourneau 1982; Andow 1991; Andres 1982). This is consistent with the natural 
enemy hypothesis which states that "crop diversification favours the natural enemies of crop pests, mainly by providing them with additional and supplementary resources" (Helenius 1989). Altieri and Letourneau (1982) recommended increasing weed diversity in the form of weed borders, alternating rows or selected periods of weed release. More information is needed on the incidence of herbivores in association with IWM.

\section{Community interactions}

A more diverse weed community likely would exhibit more weed-weed interactions (Table 3), particularly if higher weed densities were present. Although weed species in cropping systems generally have been examined individually, it may be possible to identify competitive relationships among species (Roush and Radosevich 1985). It may be useful to construct competitive hierarchies for weed species in alternative management systems (Keddy and Shipley 1989; Miller and Werner 1987; Mitchley and Grubb 1986), although there may be difficulties associated with such an approach (Silvertown and Dale 1991).

Potential beneficial interactions among weeds or between weeds and crops should also be investigated. These include improvement of the soil or microclimate, providing physical support, transferring nutrients, deterring predators or parasites, reducing the impact of other competitors, encouraging beneficial rhizosphere components and attracting pollinators or dispersal agents (Hunter and Aarssen 1988). Some weed species may be manipulated to function as cover crops. It may be possible to identify weed species that could play beneficial roles in simultaneously promoting biological control and competing with other weeds. Analogous species of arthropod pests that compete with more serious pests without causing serious damage themselves have been recognized (Croft and Hoying 1977; Moon 1980).

In the development of strategies for community management, increased weed-weed interactions could allow the adjustment of economic thresholds (Table 3). It may be useful to determine if significant interactions occur among weed populations that are suppressed below economic thresholds. Also, weeds may approach fairly high densities without the need for control, such as in the early seedling stage or late in the season when weed abundance no longer influences crop yield. There is also the potential for indirect effects, such as the gradual replacement of species adapted to former management practices by species adapted to the new practices.

\section{Community dynamics}

Agricultural weed communities are generally unstable because eradication or near eradication of some weed species creates a vacuum that may encourage future weed outbreaks. In considering the potential role of stability in more diverse systems, it must be remembered that there is no direct relationship between diversity and stability (Goodman 1975). However, stabilizing influences on community dynamics can be recognized. Thus, changes resulting in increased diversity under IWM may support an improved chance of greater community stability (Table 3). A more stable weed community may lead to improved predictability of weed dynamics and more proactive weed management.

Instability may also result from increased diversity, particularly if accompanied by higher weed populations than normally encountered in conventional systems. One of the most important causes of instability of weed populations is the large and potentially volatile seedbanks of some of the more dominant weeds (Cavers and Benoit 1989). With greater diversity under IWM, seed bank dynamics may become more stable, particularly if the seedbank contains a smaller fraction of seeds from traditionally dominant weeds. Such a change might arise if the traditionally dominant weeds were reduced aboveground, thus reducing seed production by these species.

Merely increasing diversity will not likely produce an ideal system. The onus is on the IWM approach to produce the desired community structure (Table 3 ). An IWM program should take all aspects of the cropping system into considera- 
tion within a multidisciplinary approach and should be flexible to adjust to changing factors while at the same time incorporating the long-term impact of specific measures (Swanton and Weise 1991).

\section{CONCLUSION}

The number of weed species found in cropland likely will increase as alternative management practices are adopted under IWM. However, if the increase in diversity does not affect community structure significantly, and the same species are dominant as before, the management implications would be few. If, on the other hand, the number of species increases enough to change the dominance pattern, or the evenness of the weed community increases, the weedcrop competitive interactions would be affected. More observations are needed to evaluate weed communities in connection with alternative management practices, employing techniques that have been used to evaluate natural systems. However, the alternative management practices associated with IWM are still evolving, and as part of this evolution, basic ecological research must be conducted before the diversity implications can be assessed fully.

The use of alternative practices for weed management should encourage greater involvement of principles from community ecology in weed management. Some practices associated with IWM (Swanton and Weise 1991), such as conservation tillage, reduced herbicide inputs and critical period strategies, tend to promote higher weed diversity, while others, such as improvement of crop competitiveness and alternative control methods, tend to reduce diversity in themselves, but are part of an integrated package that allows for the persistence of the weed population below a defined economic threshold. If evaluations of weed community diversities reveal increases in the number of species that make up these populations, particularly if relative abundance patterns change, the structure and properties of the community will be changed. Changes could occur in the influence of colonization, disturbance, the physical environment and other communities on the vreed community.

There is a risk that these changes could create serious weed problems if ecological features are not properly understood. Information describing ecological features of weed communities in an agricultural setting is lacking. Detailed research into the various community interactions in agricultural weed communities, using approaches grounded in ecological studies of more natural systems, could form a basis for predicting and understanding the dynamics of diverse weed communities. Although there is no simple relationship between diversity and stability (Goodman 1975), factors contributing to stability may be elucidated, and this could form an important aspect of weed community diversity studies. Ultimately, this knowledge could be used to develop IWM strategies aimed toward producing a more stable, sustainable system. Given the increased attention paid to agroecosystem biodiversity from the point of view of conservation biology (Kevan et al. 1990; Paoletti et al. 1992), it may also be wise to adopt strategies for managing weed communities that promote weed species diversity.

\section{ACKNOWLEDGEMENT}

We gratefully acknowledge valuable comments on the manuscript by Peter Kevan, Doug Larson, Spencer Barrett and Stephen Murphy, and helpful input from members of the weed group in the Crop Science Department, University of Guelph.

Aldrich, R.J. 1987. Predicting crop yield reductions from weeds. Weed Technol. 1: 199206.

Altieri, M.A., and D.K. Letourneau. 1982. Vegetation management and biological control in agroecosystems. Crop Prot. 1: 405-430.

Andow, D.A. 1991. Vegetational diversity and arthropod population response. Annu. Rev. Entomol. 36: 561-586.

Andres, L.A. 1982. Integrating weed biological control agents into a pest-management program. Weed Sci. 30 (Suppl.): 25-30.

Auld, B.A., and C.A. Tisdell. 1987. Economic thresholds and response to uncertainty in weed control. Agric. Syst. 25: 219-227. 
Ayres, P.G., and N.D. Paul. 1990. The effects of disease on interspecific plant competition. Aspects Appl. Biol. 24: 155-162.

Barrett, S.C.H. 1992. Genetics of weed invasions. Pages 91-119 in S.K. Jain and L.W. Liebman (eds.), Applied population biology. Kluwer Academic Publishers, The Netherlands.

Basore, N.S., L.B. Best, and J.B. Wooley, Jr. 1986. Bird nesting in lowa no-tillage and tillage cropland. J. WildI. Manage. 50: 19-28.

Begon, M., J.L. Harper, and C.R. Townsend. 1990. Ecology: individuals, populations and communities. Blackwell Scientific Publications, Cambridge, MA. 945 pp.

Beyrouty, C.A., and D.M. Oosterhuis. 1989. The porous-membrane technique for root studies of field-grown crops. Plant Soil 116: 265-271.

Blumberg, A.Y., and D.A. Crossley, Jr. 1983. Comparison of soil surface arthropod populations in conventional tillage, no-tillage and old field systems. Agri-Ecosystems 8: 247-253.

Brain, P., and R. Cousens. 1990. The effect of weed distribution on predictions of yield loss. J. Ecol. 27: 735-742.

Brown, J.H. 1981. Two decades of homage to Santa Rosalia: toward a general theory of diversity. Am. Zool. 21: 877-888.

Brust, G.E., and G.J. House. 1988. Weed seed destruction by arthropods and rodents in low-input soybean agroecosystems. Am. J. Alternative Agric. 3: 19-25.

Bullock, D.G. 1992. Crop rotation. Crit. Rev. Plant Sci. 11: 309-326.

Cardina, J., E. Regnier, and K. Harrison. 1991. Long-term tillage effects on seed banks in three Ohio soils. Weed Sci. 39: 186-194.

Cavers, P.B., and D.L. Benoit. 1989. Seed banks in arable land. Pages 309-328 in M. A. Leck, V.T. Parker, and R.L. Simpson (eds.), Ecology of soil seed banks. Academic Press, San Diego, CA.

Chancellor, R.J. 1979. The long-term effects of herbicides on weed populations. Ann. Appl. Biol. 91: 141-144.

Chaneton, E.J., and J.M. Facelli. 1991. Disturbance effects on plant community diversity: spatial scales and dominance hierarchies. Vegetatio 93: 143-155.

Conn, J.S., and J.A. Delapp. 1983. Weed species shifts with increasing field age in Alaska. Weed Sci. 31: 520-524.

Connell, J.H. 1978. Diversity in tropical rain forests and coral reefs. Science (Washington DC) 199: 1302-1310.

Cousens, R. 1987. Theory and reality of weed control thresholds. Plant Prot. Q. 2: 13-20.

Cousens, R. 1988. Misinterpretations of results in weed research through inappropriate use of statistics. Weed Res. 28: 281289.
Croft, B.A., and S.A. Hoying. 1977. Competitive displacement of Panonychus ulmi (Acarina: Tetranychidae) by Aculus schlechtendali (Acarina: Eriophyidae) in apple orchards. Can. Entomol. 109: 10251034.

Derksen, D.A. 1991. The influence of agronomic practices on weed communities. Ph.D. thesis, University of Guelph, Guelph, ON. $224 \mathrm{pp}$.

Derksen, D.A., A.G. Thomas, G.P. Lafond, H.A. Loeppky, and C.J. Swanton. 1993. The influence of agronomic practices on weed communities: tillage systems. Weed Sci. 41: 409-417.

Dibo, A. 1991. Effect of crop density on weed competition in maize (Zea mays L.). M.Sc. thesis, University of Guelph, Guelph, ON. $92 \mathrm{pp}$.

Douglas, B.J., A.G. Thomas, and D.A. Derksen. 1990. Downy brome (Bromus tectorum) invasion into southwestern Saskatchewan. Can. J. Plant Sci. 70: 1143-1152.

Duebbert, H.F., and H.A. Kantrud. 1987. Use of no-till winter wheat by nesting ducks in North Dakota. J. Soil Water Conserv. 42: 50-53.

Elton, C. 1958. The Ecology of invasion by plants and animals. Methuen, London. 181 pp.

Evetts, L.L., and O.C. Burnside. 1975. Effect of early competition on growth of common milkweed. Weed Sci. 23: 1-3.

Frick, B., and A.G. Thomas. 1992. Weed surveys in different tillage systems in southwestern Ontario field crops. Can. J. Plant Sci. 72: 1337-1347.

Froud-Williams, R.J. 1988. Changes in weed flora with different tillage and agronomic management systems. Pages 213-236 in M.A. Altieri and M. Liebman (eds.), Weed management in agroecosystems: ecological approaches. CRC Press, Boca Raton, FL.

Froud-Williams, R.J., D.S.H. Drennan, and R.J. Chancellor. 1983. Influence of cultivation regime on weed floras of arable cropping systems. J. Appl. Ecol. 20: 187-197.

Gibson, C.W.D., and V.K. Brown. 1991. The effects of grazing on local colonisation and extinction during early succession. J. Veg. Sci. 2: 291-300.

Gitay, H., and A.D.Q. Agnew. 1989. Plant community structure, connectance, niche limitation and species guilds within a dune slack grassland. Vegetatio 83: 241-248.

Goodman, D. 1975. The theory of diversitystability relationships in ecology. $Q$. Rev. Biol. 50: 237-266.

Grime, J.P. 1973. Competitive exclusion in herbaceous vegetation. Nature (Lond.) 242: 344-347. 
Grime, J.P. 1979. Plant strategies and vegetation processes. Wiley, New York. 222 pp.

Haas, H., and J.C. Streibig. 1982. Changing patterns of weed distribution as a result of herbicide use and other agronomic factors. Pages 57-79 in H.M. LeBaron and J. Gressel (eds.), Herbicide resistance in plants. John Wiley and Sons, New York.

Hall, M.R., C.J. Swanton, and G.W. Anderson. 1992. The critical period of weed control in grain corn (Zea mays). Weed Sci. 40: 441-447.

Harper, J.L. 1957. Ecological aspects of weed control. Outlook Agric. 1: 197-205.

Heatherly, L.G., R.A. Wesley, and C.D. Elmore. 1990. Corn, sorghum, and soybean response to irrigation in the Mississippi river alluvial plain. Crop Sci. 30: 664-672.

Helenius, J. 1989. The influence of mixed intercropping of oats with field beans on the abundance and spatial distribution of cereal aphids (Homoptera: Aphididae). Agric. Ecosyst. \& Environ. 25: 53-73.

Hendrix, P.E., R.W. Parmelee, D.A. Crossley, Jr., D.C. Coleman, E.P. Odum, and P. M. Groffman. 1986. Detritus food webs in conventional and no-tillage agroecosystems. BioScience 36: 374-380.

Hidalgo, B., M. Saavedra, and L. Garcia-Torres. 1990. Weed flora of dryland crops in the Cordoba region (Spain). Weed Res. 30: 309318.

Hinkle, M.K. 1983. Problems with conservation tillage. J. Soil Water Conserv. 38: 201206.

Hodgson, J.G. 1986. Commonness and rarity in plants with special reference to the Sheffield flora. Part II: The relative importance of climate, soils and land use. Biol. Conserv. 36: 253-274.

Holzner, W. 1978. Weed species and weed communities. Vegetatio 38: 13-20.

House, G.J., and G.E. Brust. 1989. Ecology of low-input, no-tillage agroecosystems. Agric. Ecosyst. \& Environ. 27: 331-345.

House, G.J., and R.W. Parmelee. 1985. Comparison of soil arthropods and earthworms from conventional and no-tillage agroecosystems. Soil \& Tillage Res. 5: 351-360.

Hughes, G. 1990. The problem of weed patchiness. Weed Res. 30: 223-224.

Hume, L. 1982. The long-term effects of fertilizer applications and three rotations on weed communities in wheat (after 21-22 years at Indian Head, Saskatchewan). Can. J. Plant Sci. 62: 741-750.

Hume, L. 1987. Long-term effects of 2,4-D application on plants. I. Effects on the weed community in a wheat crop. Can. J. Bot. 65: $2530-2536$.

Hume, L. 1988. Long-term effects of 2,4-D application on plants. II. Herbicide avoidance by Chenopodium album and Thlaspi arvense. Can. J. Bot. 66: 230-235.
Hunter, A.F., and L.W. Aarssen. 1988. Plants helping plants. BioScience 38: 34-40.

Jordan, N. 1992. Weed demography and populations dynamics: implications for threshold management. Weed Technol. 6: 184-190.

Keddy, P.A., and B. Shipley. 1989. Competitive hierarchies in herbaceous plant communities. Oikos 54: 234-241.

Kevan, P.G., E.A. Clark, and V.G. Thomas. 1990. Insect pollinators and sustainable agriculture. Am. J. Alternative Agric. 5: 1322.

Kikkawa, J. 1986. Complexity, diversity and stability. Pages 41-62 in J. Kikkawa and D.J. Anderson (eds.), Community ecology: pattern and process. Blackwell Scientific, Melbourne.

Kolosa, J., and D. Strayer. 1988. Patterns of the abundance of species: a comparison of two hierarchical models. Oikos 53: 235341.

Koskinen, W.C., and C.G. McWhorter. 1986. Weed control in conservation tillage. J. Soil Water Conserv. 38: 253-254.

Kull, K., and M. Zobel. 1991. High species richness in an Estonian wooded meadow. J. Veg. Sci. 2: 711-714.

Légère, A., and J.-M. Deschênes. 1989. Effects of time of emergence, population clensity and interspecific competition on hempnettle (Galeopsis tetrahit) seed production. Can. J. Plant Sci. 69: 185-194.

Lepš, J., and J. Stursa. 1989. Species-area curve, life history strategies, and succession: a field test of relationships. Vegetatio 83: 249-257.

Luken, J.O. 1990. Directing ecological succession. Chapman and Hall, London. 251 pp.

MacArthur, R.H. 1972. Geographical ecology. Harper \& Row, New York. 269 pp.

Magurran, A. E. 1988. Ecological diversity and its measurement. Princeton Univ. Press, Princeton, NJ. 179 pp.

Mahn, E.G. 1984. Structural changes of weed communities and populations. Vegetatio 58: 79-85.

Martin, T.J. 1987. Broad versus narrowspectrum herbicides and the future of mixtures. Pestic. Sci. 20: 289-299.

Maurer, B.A. 1987. Scaling of biological community structure: a systems approach to community complexity. J. Theor. Biol. 127: 97-110.

Maxwell, B.D., and C. Ghersa. 1992. The influence of weed seed dispersion versus the effect of competition on crop yield. Weed Technol. 6: 196-204.

May, R.M. 1971. Stability in a multispecies community. Math. Biosci. 12: 59-79. 
May, R.M. 1972. Will a large complex system be stable? Nature (Lond.) 238: 413-414.

May, R.M. 1973. Stability and complexity in model ecosystems. Princeton Univ. Press, Princeton, NJ. 235 pp.

McBrien, H., R. Harmsen, and A. Crowder. 1983. A case of insect grazing affecting plant succession. Ecology 64: 1035-1039.

McGonigle, T.P., D.G. Evans, and M.H. Miller. 1990. Effect of degree of soil disturbance on mycorrhizal colonization and phosphorus absorption by maize in growth chamber and field experiments. New Phytol. 116: $629-636$

Mclntyre, S., C.M. Finlayson, P.Y. Ladiges, and D.S. Mitchell. 1991. Weed community composition and rice husbandry practices in New South Wales, Australia. Agric. Ecosyst. \& Environ. 35: 27-45.

Mesléard, F., P. Grillas, and J. Leport. 1991. Plant community succession in a coastal wetland after abandonment of cultivation: the example of the Rhone delta. Vegetatio 94: 35-45.

Miller, T.E., and P.A. Werner. 1987. Competitive effects and responses between plant species in a first-year old-field community. Ecology 68: 1201-1210.

Mitchley, J., and P.J. Grubb. 1986. Control of relative abundance of perennials in chalk grassland in southern England. I. Constancy of rank order and results of pot and field experiments on the role of interference. J. Ecol. 74: 1139-1166.

Mohler, C.L., and M. Liebman. 1987. Weed productivity and composition in sole crops and intercrops of barley and field pea. J. Appl. Ecol. 24: 685-699.

Moon, R.D. 1980. Biological control through interspecific competition. Environ. Entomol. 9: 723-728.

Moore, M.J. 1992. Cover crop effect on weed emergence, weed suppression, and soybean [Glycine max (L.) Merrill] development. M.Sc. thesis, University of Guelph, Guelph, ON. 89 pp.

Murdoch, W.W. 1975. Diversity, complexity, stability and pest control. J. Appl. Ecol. 12: 795-807.

Nissanka, S.P. 1991. Impact of corn (Zea mays L.) hybrids and nitrogen fertilization on weed-crop competition. M.Sc. thesis, University of Guelph, Guelph, ON. 89 pp.

Norris, R.F. 1992. Case history for weed competition/population ecology: barnyardgrass (Echinochloa crus-galli) in sugarbeets (Beta vulgaris). Weed Technol. 6: 220-227.

Noss, R.F. 1990. Indicators for monitoring biodiversity: a hierarchical approach. Conserv. Biol. 4: 355-364.
Odum, E.P. 1963. Ecology. Holt, Rinehart and Winston, New York. 152 pp.

Odum, E.P. 1969. The strategy of ecosystem development. Science (Washington DC) 164: $262-270$.

Pacala, S.W., and J.A. Silander, Jr. 1987. Neighborhood interference among velvetleaf, Abutilon theophrasti, and pigweed, Amaranthus retroflexus. Oikos 48: 217-224.

Pannell, D.J. 1990. Responses to risk in weed control decisions under expected profit maximization. J. Agric. Econ. 41: 391-404.

Paoletti, M.G., D. Pimentel, B.R. Stinner, and D. Stinner. 1992. Agroecosystem biodiversity: matching production and conservation biology. Agric. Ecosyst. \& Environ. 40: 3-23.

Parmelee, R.W., M.H. Beare, W. Cheng, P.F. Hendrix, S.J. Rider, D.A. Crossley, Jr., and D.C. Coleman. 1990. Earthworms and enchytraeids in conventional and notillage agroecosystems: a biocide approach to assess their role in organic matter breakdown. Biol. Fertil. Soils 10: 1-10.

Petraitis, P.S., R.E. Latham, and R.A. Niesenbaum. 1989. The maintenance of species diversity by disturbance. Q. Rev. Biol. 64: 393-418.

Pianka, E.R. 1980. Guild structure in desert lizards. Oikos 35: 194-201.

Pickett, S.T.A., and F.A. Bazzaz. 1978. Organization of an assemblage of early successional species on a soil moisture gradient. Ecology 59: 1248-1255.

Pickett, S.T.A., S.L. Collins, and J.J. Armesto. 1987. A hierarchical consideration of causes and mechanisms of succession. Vegetatio 69: 109-114.

Pielou, E.C. 1966. Species-diversity and pattern-diversity in the study of ecological succession. J. Theor. Biol. 10: 370-383.

Pimm, S.L. 1984. The complexity and stability of ecosystems. Nature (Lond.) 307: 321-326.

Pyšek, P., and J. Lepš. 1991. Response of a weed community to nitrogen fertilization: a multivariate analysis. J. Veg. Sci. 2: 237244.

Radosevich, S.R. 1987. Methods to study interactions among crops and weeds. Weed Technol. 1: 190-198.

Radosevich, S.R., and J.S. Holt. 1984. Weed ecology: implications for vegetation management. Wiley and Sons, Toronto, ON. $265 \mathrm{pp}$.

Rodgers, R.D., and J.B. Wooley. 1983. Conservation tillage impacts on wildlife. J. Soil Water Conserv. 38: 212-213.

Roush, M.L., and S.R. Radosevich. 1985. Relationships between growth and competitiveness of four annual weeds. J. Appl. Ecol. 22: 895-905. 
Sagar, G.R., and J.L. Harper. 1961. Controlled interference with natural populations of Plantago lanceolata, P. major and P. media. Weed Res. 1: 163-176.

Salonen, V. 1989. Weed communities of cereal crops grown on differently revegetated cut-over peatland sites. J. Appl. Ecol. 26: 563-569.

Scheiner, S.M. 1992. Measuring pattern diversity. Ecology 73: 1860-1867.

Shaltout, K.H., and R.A. El Fahar. 1991. Diversity and phenology of weed communities in the Nile Delta region. J. Veg. Sci. 2: 385390.

Silvertown, J., and P. Dale. 1991. Competitive hierarchies and the structure of herbaceous plant communities. Oikos 61: 441-444.

Slife, F.W. 1981. Environmental control of weeds. Pages 485-491 in Handbook of pest management in agriculture. Vol. 1. CRC Press, Boca Raton, FL.

Sugihara, G. 1980. Minimal community structure: an explanation of species abundance patterns. Am. Nat. 116: 770-787.

Swanton, C.J., and S.F. Weise. 1991. Integrated weed management in Ontario: the rationale and approach. Weed Technol 5: 657663.

Swanton, C.J., D.R. Clements, and D.A. Derksen. 1993. Weed succession under conservation tillage: a hierarchical framework for research and management. Weed Technol. 7: 286-297.

Thomas, A.G. 1985. Weed survey system used in Saskatchewan for cereal and oilseed crops. Weed Sci. 33: 34-43.

Thomas, A.G., and J.A. Ivany. 1990. The weed flora of Prince Edward Island cereal fields. Weed Sci. 38: 119-124.

Thompson, K., and J.P. Grime. 1979. Seasonal variation in the seed banks of herbaceous species in ten contrasting habitats. J. Ecol. 67: 893-921.

Tilman, D. 1982. Resource competition and community structure. Princeton Univ. Press, Princeton, NJ. 296 pp.

Topham, P.B., and H.M. Lawson. 1982. Measurement of weed species diversity in crop/weed competition studies. Weed Res.
Unger, P.W. 1984. Tillage effects on surface soil physical conditions and sorghum emergence. Soil Sci. Soc. Am. J. 46: 796-801.

Van Acker, R.C. 1992. The critical period of weed control in soybean (Glycine max (L.) Merr.) and the influence of weed interference on soybean growth. M.Sc. thesis, University of Guelph, Guelph, ON. 103 pp.

Van Acker, R.C., C.J. Swanton, and S.F. Weise. 1993. The critical period of weed control in soybean (Glycine max (L.) Merr.). Weed Sci. 41: 194-200.

Van Emden, H.F., and G.F. Williams. 1974. Insect stability and diversity in agroecosystems. Annu. Rev. Entomol. 19: 455-475.

Walker, D. 1989. Diversity and stability. Pages 115-146 in J.M. Cherrett, A.D. Bradshaw, F.B. Goldsmith, P.J. Grubb, and J.R. Krebs (eds), Ecological concepts. Blackwell Scientific Publications, London.

Warburton, D.B., and W.D. Klimstra. 1984. Wildlife use of no-till and conventionaltilled corn fields. J. Soil Water Conserv. 39: 327-330.

Weaver, S.E. 1984. Critical period of weed competition in three vegetable crops in relation to management practices. Weed Res. 24: 317-325.

Wentworth, T.R., J.S. Conn, W.A. Skroch, and E. Mrozek, Jr. 1984. Gradient analysis and numerical classification of apple orchard weed vegetation. Agric. Ecosyst. \& Environ. 11: 239-251.

Whittaker, R.H. 1965. Dominance and diversity in land plant communities. Science (Washington DC) 147: 250-260.

Woolhouse, M.E.J., and R. Harmsen. 1987. Just how unstable are agroecosystems? Can. J. Zool. 65: 1577-1580.

Woolley, B.L., T.E. Michaels, M.R. Hall, and C.J. Swanton. 1993. The critical period of weed control in white bean, Phaseolus vulgaris. Weed Sci. 41: 180-184.

Zanin, G., and M. Sattin. 1988. Threshold level and seed production of velvetleaf (AbutiIon theophrasti (L.) Medicus) in maize. Weed Res. 28: 347-352. 